Fixed Point Theory, 20(2019), No. 1, 113-134

DOI: $10.24193 /$ fpt-ro.2019.1.07

http://www.math.ubbcluj.ro/ nodeacj/sfptcj.html

\title{
SYSTEMS OF VARIATIONAL INEQUALITIES WITH HIERARCHICAL VARIATIONAL INEQUALITY CONSTRAINTS FOR LIPSCHITZIAN PSEUDOCONTRACTIONS
}

\author{
LU-CHUAN CENG*, ADRIAN PETRUŞEL**, JEN-CHIH YAO*** AND YONGHONG YAO**** \\ *Department of Mathematics, Shanghai Normal University \\ Shanghai 200234, China \\ E-mail: zenglc@hotmail.com \\ ** Department of Mathematics, Babeş-Bolyai University \\ Kogălniceanu Str., no. 1, 400084 Cluj-Napoca, Romania \\ E-mail: petrusel@math.ubbcluj.ro \\ ${ }^{* * *}$ Center for General Education, China Medical University \\ Taichung 40402, Taiwan \\ and \\ Department of Applied Mathematics, National Sun Yat-sen University \\ Kaohsiung, Taiwan 804 \\ E-mail: yaojc@mail.cmu.edu.tw \\ **** Corresponding author. Department of Mathematics \\ Tianjin Polytechnic University \\ Tianjin 300387, China \\ and \\ School of Mathematics and Information Science, North Minzu University \\ Yinchuan, 750021, China \\ E-mail: yaoyonghong@aliyun.com
}

\begin{abstract}
In this paper, we consider the problem of solving a general system of variational inequalities (GSVI) with a hierarchical variational inequality (HVI) constraint for countably many uniformly Lipschitzian pseudocontractive mappings and an accretive operator in a real Banach space. We propose an implicit composite extragradient-like method based on the Mann iteration method, the viscosity approximation method and the Korpelevich extragradient method. Convergence results for the proposed iteration method are also established under some suitable assumptions.

Key Words and Phrases: Implicit composite extragradient-like method, general system of variational inequalities, fixed point, accretive operator, uniform convexity, uniform smoothness.

2010 Mathematics Subject Classification: 49J30, 47H09, 47H10, 47J20.

*This research was partially supported by the Innovation Program of Shanghai Municipal Education Commission (15ZZ068), Ph.D. Program Foundation of Ministry of Education of China (20123127110002) and Program for Outstanding Academic Leaders in Shanghai City (15XD1503100)

** This research was partially supported by the grant MOST 106-2923-E-039-001-MY3.
\end{abstract}




\section{REFERENCES}

[1] Q.H. Ansari, A. Rehan, C.-F. Wen, Split hierarchical variational inequality problems and fixed point problems, J. Ineq. Appl., 2015 (2015), Article ID 793.

[2] Q.H. Ansari, J.-C. Yao, A fixed point theorem and its applications to the system of variational inequalities, Bull. Austral. Math. Soc., 59(1999), 433-442.

[3] Q.H. Ansari, J.-C. Yao, Systems of generalized variational inequalities and their applications, Applicable Anal., 76(2000), 203-217.

[4] K. Aoyama, Y. Kimura, W. Takahashi, M. Toyoda, Approximation of common fixed points of a countable family of nonexpansive mappings in a Banach space, Nonlinear Anal., 67(2007), 2350-2360.

[5] R.E. Bruck Jr., Properties of fixed-point sets of nonexpansive mappings in Banach spaces, Trans. Amer. Math. Soc., 179(1973), 251-262.

[6] L.-C. Ceng, S. Al-Mezel, Q.H. Ansari, Implicit and explicit iterative methods for systems of variational inequalities and zeros of accretive operators, Appl. Abstract Anal., 2013 (2013), Article ID 631382, 19 pages.

[7] L.C. Ceng, Q.H. Ansari, J.C. Yao, Mann-type steepest-descent and modified hybrid steepestdescent methods for variational inequalities in Banach spaces, Numer. Funct. Anal. Optim., 29(2008), 987-1033.

[8] L.C. Ceng, H. Gupta, Q.H. Ansari, Implicit and explicit algorithms for a system of nonlinear variational inequalities in Banach spaces, J. Nonlinear Convex Anal., 16(2015), 965-984.

[9] L.C. Ceng, A. Latif, J.C. Yao, On solutions of a system of variational inequalities and fixed point problems in Banach spaces, Fixed Point Theory Appl., 2013, 2013:176, 34 pp.

[10] L.C. Ceng, Y.C. Liou, C.F. Wen, Systems of variational inequalities with hierarchical variational inequality constraints in Banach spaces, J. Nonlinear Sci. Appl., 10(2017), 3136-3154.

[11] L.C. Ceng, A. Petruşel, M.M. Wong, S.J. Yu, Strong convergence of implicit viscosity approximation methods for pseudocontractive mappings in Banach spaces, Optimization, 60(2011), 659-670.

[12] L.C. Ceng, S. Plubtieng, M.M. Wong, J.C. Yao, System of variational inequalities with constraints of mixed equilibria, variational inequalities, and convex minimization and fixed point problems, J. Nonlinear Convex Anal., 16(2015) 385-421.

[13] L.C. Ceng, C.Y. Wang, J.C. Yao, Strong convergence theorems by a relaxed extragradient method for a general system of variational inequalities, Math. Methods Oper. Res., 67(2008), 375-390.

[14] L.C. Ceng, C.F. Wen, Three-step Mann iterations for a general system of variational inequalities and an infinite family of nonexpansive mappings in Banach spaces, J. Ineq. Appl. 2013, 2013:539, 27 pp.

[15] L.C. Ceng, C.F. Wen, System of variational inequalities and an accretive operator in Banach spaces, Fixed Point Theory Appl., 2013, 2013:249, 37 pp.

[16] L.C. Ceng, H.K. Xu, Strong convergence of a hybrid viscosity approximation method with perturbed mappings for nonexpansive and accretive operators, Taiwanese J. Math., 11(2007), 661682.

[17] R.D. Chen, Z.C. Zhu, Viscosity approximation of fixed points for nonexpansive and m-accretive operators, Fixed Point Theory Appl., 2006, Article ID 81325, 10 pp.

[18] S.Y. Cho, X. Qin, J.C. Yao, Y. Yao, Viscosity approximation splitting methods for monotone and nonexpansive operators in Hilbert spaces, J. Nonlinear Convex Anal., 19(2018), 251-264.

[19] K. Deimling, Zeros of accretive operators, Manuscripta Math., 13(1974), 365-374.

[20] F. Facchinei, J.S. Pang, Finite-Dimensional Variational Inequalities and Complementarity Problems I, Springer-Verlag, New York, 2003.

[21] K. Goebel, W.A. Kirk, A fixed point theorem for asymptotically nonexpansive mappings, Proc. Amer. Math. Soc., 35(1972) 171-174.

[22] S. Kamimura, W. Takahashi, Strong convergence of a proximal-type algorithm in a Banach space, SIAM J. Optim., 13(2002) 938-945.

[23] T.C. Lim, H.K. Xu, Fixed point theorems for asymptotically nonexpansive mappings, Nonlinear Anal., 22(1994), 1345-1355. 
[24] L.-J. Lin, Q.H. Ansari, Collective fixed points and maximal elements with applications to abstract economies, J. Math. Anal. Appl., 296(2004), 455-472.

[25] R.H. Martin Jr., Differential equations on closed subsets of a Banach space, Trans. Amer. Math. Soc., 179(1973), 399-414.

[26] S. Reich, Weak convergence theorems for nonexpansive mappings in Banach spaces, J. Math. Anal. Appl., 67(1979), 274-276.

[27] T. Suzuki, Strong convergence of Krasnoselskii and Mann's type sequences for one-parameter nonexpansive semigroups without Bochner integrals, J. Math. Anal. Appl., 305(2005), 227-239.

[28] W. Takahashi, Nonlinear Functional Analysis, Yokohama Publisher, Yokohama, 2000.

[29] W. Takahashi, C.F. Wen, J.C. Yao, Split common fixed point problems and hierarchical variational inequality problems in Hilbert spaces, J. Nonlinear Convex Anal., 18(2017), 925-935.

[30] R.U. Verma, General convergence analysis for two-step projection methods and applications to variational problems, Appl. Math. Lett., 18(2005), 1286-1292.

[31] H.K. Xu, Inequalities in Banach spaces with applications, Nonlinear Anal., 16(1991), 1127-1138.

[32] H.K. Xu, Viscosity approximation methods for nonexpansive mappings, J. Math. Anal. Appl., 298(2004), 279-291.

[33] Y. Yao, Y.C. Liou, J.C. Yao, Iterative algorithms for the split variational inequality and fixed point problems under nonlinear transformations, J. Nonlinear Sci. Appl., 10(2017), 843-854.

[34] Y. Yao, A. Petrusel, X. Qin, An improved algorithm based on Korpelevich's method for variational inequalities in Banach spaces, J. Nonlinear Convex Anal., 19(2018), 397-405.

[35] Y. Yao, M. Postolache, Y.C. Liou, Z. Yao, Construction algorithms for a class of monotone variational inequalities, Optim. Lett., 10(2016), 1519-1528.

[36] Y. Yao, X. Qin, J.-C. Yao, Projection methods for firmly type nonexpansive operators, J. Nonlinear Convex Anal., 19(2018), 407-415.

[37] H. Zegeye, N. Shahzad, Y. Yao, Minimum-norm solution of variational inequality and fixed point problem in Banach spaces, Optimization, 64(2015), 453-471.

Received: December 17, 2017; Accepted: February 9, 2018. 
